University of Wollongong

Research Online

Faculty of Social Sciences - Papers (Archive) Faculty of Arts, Social Sciences \& Humanities

$1-1-2013$

More than beliefs: Subject-areas and teachers' integration of laptops in secondary teaching

Sarah K. Howard

University of Wollongong, sahoward@uow.edu.au

Amy Y. C. Chan

University of Wollongong, amychan@uow.edu.au

Peter Caputi

University of Wollongong, pcaputi@uow.edu.au

Follow this and additional works at: https://ro.uow.edu.au/sspapers

Part of the Education Commons, and the Social and Behavioral Sciences Commons

Research Online is the open access institutional repository for the University of Wollongong. For further information contact the UOW Library: research-pubs@uow.edu.au 


\title{
More than beliefs: Subject-areas and teachers' integration of laptops in secondary teaching
}

\author{
Abstract \\ Abstract presented at the 15th Biennial EARLI Conference for Research on Learning and Instruction, 27-31 \\ Aug 2013, Munich, Germany \\ Keywords \\ beliefs, integration, subject, areas, teachers, laptops, secondary, more, teaching, than \\ Disciplines \\ Education | Social and Behavioral Sciences

\section{Publication Details} \\ Howard, S. K., Chan, A. Y. C. \& Caputi, P. (2013). More than beliefs: Subject-areas and teachers' integration \\ of laptops in secondary teaching. Responsible Teaching and Sustainable Learning: 15th Biennial EARLI \\ Conference for Research on Learning and Instruction - Book of abstracts and extended summaries ( $p$. \\ 649). EARLI.
}




\title{
Effectivity of co-operative and individual/expert mentoring in didactic contexts
}

\author{
Ulrike Hanke \\ University of Freiburg \\ Germany \\ Pauline Viehmann \\ University of Freiburg \\ Germany
}

From the point of view of constructivist learning theories, mentoring has to be seen as an effective teaching method because it is based on the individual's difficulties and tries to solve exactly these difficulties. But on the other hand, individual mentoring is hard to realize in everyday teaching situations because it is very time consuming for the lecturer. Therefore the question emerges of whether co-operative mentoring may be as effective as individual/expert mentoring. From a theoretical point of view, it is believed that the advantages of co-operative mentoring settings may balance their disadvantages. The study presented in this paper, which was realized in a university course over one semester with 51 participants, gives first evidence that mentoring indeed supports learning and that the two forms do not differ in regard to their effectiveness.

\section{More than beliefs: Subject-areas and teachers' integration of laptops in secondary teaching}

\author{
Sarah Howard \\ University of Wollongong \\ Australia \\ Amy Chan \\ University of Wollongong \\ Australia \\ Peter Caputi \\ University of Wollongong \\ Australia
}

The purpose of this paper is to explore the possible relationship of subject areas to teachers' adoption of laptops in learning and teaching, in a large-scale 1-to-1 laptop initiative. Research in this area has confirmed that support, professional development, teacher confidence and beliefs are significant variables relating to technology integration. The following discussion argues that technology integration models should also consider subject-area factors, independent of teachers' beliefs. The inclusion of subject-area considerations would include teaching and cultural conventions, such as forms of content knowledge and disciplinary traditions. This discussion presents a descriptive analysis of four subject areas, and their relationship to teachers' technology integration. Findings suggest that 'subject area' could be included as a factor in a revised integration model. Implications for professional development in large technology-related initiatives and future research will be discussed.

\section{Measuring Problem Solving Abilities in Childhood}

David Tobinski

Institute for Psychology

Germany

Annemarie Fritz 